ISSN : 2580-3220, E-ISSN : 2580-4588

J. Mandiri., Vol. 5, No. 2, Desember 2021 (99 - 108)

(C)2017 Lembaga Kajian Demokrasi

dan Pemberdayaan Masyarakat (LKD-PM)

DOI: https://doi.org/10.33753/mandiri.v5i2.177

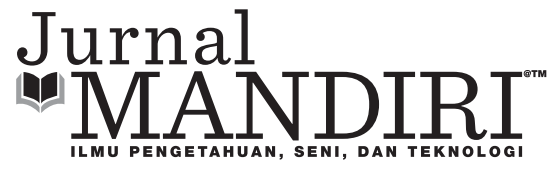

\title{
The Influence of Leadership Style and Organizational Culture on Job Satisfaction of the CUG Konsepsi Filosofi Petani Pancur Kasih Pontianak
}

\author{
Nova Arestia \\ Fakultas Ekonomi dan Bisnis, Universitas Widya Dharma Pontianak \\ novaarestia@widyadharma.ac.id
}

\begin{abstract}
The purpose of this study is to determine the influence of leadership study variables and organizational culture both simultaneously and partially on the job satisfaction of Credit Union Gerakan Konsepsi Filosofi Petani Pancur Kasih Pontianak Activists. The analytical method used is referred to as the associative method and multiple linear regression analysis. The respondents of this study are all Credit Union Gerakan Konsepsi Filosofi Petani Pancur Kasih Pontianak Activists totalling 33 people. The results of applying this study to an F test show that there is a simultaneous influence between leadership style variables and organizational culture variables on job satisfaction while the results of hypothesis testing using a T-test show that there is a partial influence between leadership style variables on job satisfaction, but there is no partial influence between organizational culture variables on job satisfaction. The conclusion from the results of this study is that the leadership style variables and organizational culture variables have a simultaneous influence on job satisfaction, and there is a partial influence of leadership style variables on job satisfaction but there is no influence of organizational culture variables on job satisfaction.
\end{abstract}

Keywords : Leadership Style, Organizational Culture, Job Satisfaction

\section{INTRODUCTION}

In an organization, human resources are an important factor that plays a role in achieving organizational goals. In addition, humans are also a resource that determines the success of achieving the organization's vision and mission. Therefore, all things including human resources must be an important concern for the management to make the employees have job satisfaction which is manifested in utmost work performance so that organizational goals can be achieved effectively and efficiently.

Job satisfaction is not only obtained from a high social status. Job satisfaction, on the employee's side, can also constitute an effort to achieve the production itself. Berliana, Siregar and Gustian (2018) state that job satisfaction in an employee's perception is the benefits obtained from work and is an important factor in understanding organizational behaviour.

Creating job satisfaction in the organization is not easy, especially for a large organization where co-operation among human resources led by a leader is absolutely necessary. Indirectly, leadership determines job satisfaction, for the reason that it can affect employees' motivation and commitment as well as a company performance both in short and long term (Kebede and Demeke, 2017). Competent leaders can also create an organizational culture, provide 
direction, coordination, and guidance in the formation of work mentality for their employees. The existence of leaders and organizational culture can affect the job satisfaction of human resources in the organization.

A good leader usually does not carry out operational actions but instead he makes decisions, policies and directs others to carry out the decisions duly taken in accordance with the policies that have been outlined. Asghar and Oino (2018) emphasize that leadership can improve the relationship between leaders and employees. The success or failure of an organization in achieving its goals is also influenced by a leader with his leadership style. Vasilescu (2019) argues that leaders through their leadership can influence employees to achieve goals either by motivating or providing rewards and sanctions according to their respective performance. But if the leader has little influence in leading the company, he can create problems related to unethical practices, high turnover of workers, poor financial performance and others (Khajeh, 2018).

Organizational culture is an invisible social force that can motivate people in an organization to carry out work activities (Sutrisno, 2018: 2). If the organizational culture is already well-formed in the employees, it will foster a great sense of responsibility in employees to achieve better goals.

The Credit Union Gerakan Konsepsi Filosofi Petani Pancur Kasih (CU GKFPPK) Pontianak is one of the largest organization that has been established since 2011. There are 33 people in the CU GKFPPK Pontianak, who are better known as activists. In addition to providing savings and loan services, the activists at CU GKFPPK Pontianak are also active in the continuous holistic empowerment of the community.

Table 1 below shows the attendance rate of CU GKFPPK Pontianak activists for the last 5 years.

From Table 1, it can be seen that the absentee level of activists in a year is still normal. This is in line with Afandi's opinion (2021: 78) which states that there is a strong negative correlation between absenteeism and satisfaction, which means that if satisfaction increases, absenteeism will decrease.

Table 1. CU GKFPPK Pontianak's activist attendance rate

\begin{tabular}{rrrrr}
\hline \multirow{2}{*}{ Year } & $\begin{array}{c}\text { Number of } \\
\text { Activists }\end{array}$ & \multicolumn{2}{c}{ Attendance Rate } & \multirow{2}{*}{ Total Absence } \\
\hline 2016 & 23 & 34 & 54 & 88 \\
2017 & 32 & 41 & 62 & 103 \\
2018 & 34 & 33 & 70 & 103 \\
2019 & 33 & 46 & 84 & 130 \\
2020 & 33 & 27 & 77 & 104 \\
\hline
\end{tabular}

Table 2. Number of turnovers CU GKFPPK Pontianak's activists

\begin{tabular}{rrrrrr}
\hline Year & $\begin{array}{c}\text { Activists } \\
\text { (Early of the Year) }\end{array}$ & \multicolumn{2}{c}{ Number of Activists } & \multicolumn{2}{c}{$\begin{array}{c}\text { Activists } \\
\text { (Entry of the Year) }\end{array}$} \\
\hline 2016 & 22 & 1 & Exit & - & 23 \\
2017 & 23 & 9 & - & 32 \\
2018 & 32 & 2 & - & 34 \\
2019 & 34 & - & 1 & 33 \\
2020 & 33 & - & - & 33 \\
\hline
\end{tabular}


Table 2 shows the number of turnovers of $\mathrm{CU}$ GKFPPK Pontianak's activists over the last 5 years.

Based on the turnover number of CU GKFPPK Pontianak's activists in Table 2, it can be seen that the number of activists is increasing from year to year. This means that the activists are satisfied with working at the CU GKFPPK Pontianak and have no desire to leave. Afandi (2021: 79) states that the relationship between turnover and satisfaction is negative, where turnover can disrupt organizational continuity. Therefore, the organization must also maintain job satisfaction of the activists in order to provide maximum contribution.

Saputra \& Adnyani (2017), Devita (2018), and Huda (2019) conducted research and got the results that leadership style and organizational culture simultaneously affected job satisfaction. The proposed hypothesis is, therefore, as follows:

$\mathrm{H} 0=$ simultaneous leadership style and organizational culture have no significant influence on job satisfaction of CU GKFPPK Pontianak activists

H1 = leadership style and organizational culture simultaneously have a significant influence on job satisfaction of CU GKFPPK Pontianak activists

The proposed hypothesis between the leadership style variable and job satisfaction variable can be formed based on research conducted by Sinurat (2017) and Rashid, Roswaty \& Kurniawan (2017) who got the results that the leadership style variable affected the job satisfaction variable.

$\mathrm{H} 0$ = leadership style has no significant influence on job satisfaction of CU GKFPPK Pontianak activists $\mathrm{H} 2$ = leadership style has a significant influence on job satisfaction of CU GKFPPK Pontianak activists

From research conducted by Sekarini (2017), and Primasheila, Hanafi \& Bakri (2017) and Tejayadi, Laba \& Pradana (2019), the results showed that organizational culture variables had an influence on job satisfaction variables, so the hypothesis proposed between organizational culture variables and job satisfaction variables are as follows:

$\mathrm{H} 0=$ organizational culture has a significant influence on job satisfaction of CU GKFPPK Pontianak activists $\mathrm{H} 3=$ organizational culture has no significant influence on job satisfaction of CU GKFPPK Pontianak activists

Based on the background duly disclosed, the problems in this study can be formulated as to whether the leadership style and organizational culture have a simultaneous and partial influence on job satisfaction of CU GKFPPK Pontianak activists. The aim of this research is to test and analyze the influence of leadership style and organizational culture simultaneously and partially on the job satisfaction of CU GKFPPK Pontianak activists.

\section{METHODS}

The research method used in this paper is referred to as associative method. The data were collected using observation, interviews, questionnaires, and literature studies that were relevant in supporting the research, including through literature studies (books, journals, internet, and literature relevant to the problem being researched). The population in this study was the $\mathrm{CU}$ GKFPPK Pontianak's activists totalling 33 people. So that the sampling method used was census method, involving 33 activists of CU GKFPPK Pontianak.

The data analysis technique used in this study was both qualitative and quantitative analysis using a Likert scale and SPSS 23.00 program. The analytical tools used are validity test, reliability test and classical assumption test (normality test, linearity test, multicollinearity test and heteroscedasticity test), F statistic test, coefficient of determination analysis test, multiple linear regression analysis, and t-test.

\section{RESULTS}

Leadership style is the overall pattern of a leader's actions towards his subordinates (Utaminingsih, 2014: 99). To achieve organizational goals, a company needs a competent leader. Utaminingsih (2014: 87) states that leadership style focuses on behaviour related to the function of a leader.

Sutrisno (2018: 2) states that organizational culture can also be referred to as corporate culture in the form of values or norms that have prevailed and taken the by employees as behavioural norms in carrying out company's activities. The values of organizational culture are believed to be the norms and values that govern the running of the company (Isac, et al., 2021). The organizational culture that has been wellformed can help the company to achieve efficiency, effectiveness, productivity, and work ethic. Onday (2016) argues that a company can make organizational culture a competitive asset that may be manipulated and managed. 
Asghar and Oino (2018) argue that job satisfaction will come about in employees when they do their work. In line with this opinion, Thiagaraj and Thangaswamy (2017) state that job satisfaction can also be termed as employees' perceptions and expectations regarding positive attitudes or pleasant emotional states derived from experiences related to their work.

Table 3 describes the statements in the questionnaire used in this study.

Table 4 describes the results of the validity test of the variables of leadership style, organizational culture, and job satisfaction.

Table 3. Research questionnaire

\begin{tabular}{|c|c|}
\hline Variable & Statement \\
\hline Leadership & 1.The manager has a clear and realistic strategy. \\
\hline \multirow[t]{12}{*}{ Style (X1) } & 2.The work strategy programs are well accepted by the activists. \\
\hline & 3.I believe that the goals set by the Manager will bring about changes for the betterment. \\
\hline & 4.The Manager personally pays attention to me and motivates my work. \\
\hline & 5.The Manager cares about problems befalling to his activists. \\
\hline & $\begin{array}{l}\text { 6.The Manager is very much concerned about work environment that makes me feel com- } \\
\text { fortable at work. }\end{array}$ \\
\hline & $\begin{array}{l}\text { 7.The Manager stimulates the activists to equip themselves with knowledge and skills in an } \\
\text { effort to increase competence. }\end{array}$ \\
\hline & 8.The Manager stimulates the activists to have a determination to thoroughly complete their tasks. \\
\hline & Manager invites all activists to be quality orientated. \\
\hline & 10.The Manager invites all activists to work in a harmonious and solid team. \\
\hline & 11.The Manager can well resolve any conflicts taking place among the activists. \\
\hline & 12.The Manager appreciates any differences in opinion for a better goal. \\
\hline & 13.The Manager invites all activists to respect any differences and beliefs. \\
\hline Organiza- & 1.I am fully satisfied with the work that I have done. \\
\hline & 2.I am trying to develop my capabilities and abilities. \\
\hline \multirow{14}{*}{$\begin{array}{l}\text { Culture } \\
(\mathrm{X} 2)\end{array}$} & 3.I obey all existing rules \\
\hline & 4.I make every effort possible to provide the best services to all members. \\
\hline & $\begin{array}{l}\text { 5.In carrying out my works, I take up the initiatives and try not to depend solely on the direc- } \\
\text { tions provided by the Manager. }\end{array}$ \\
\hline & $\mathrm{h}$ them well. \\
\hline & tivists respect each other, greet and say hello when they meet. \\
\hline & ect and ser \\
\hline & 9.Each section views others as internal activists that must be served. \\
\hline & 10.I assist others who are less proficient at work. \\
\hline & 11.I try to convince others who have different opinions. \\
\hline & 12.I prioritize quality in completing my works. \\
\hline & te to find new and useful things. \\
\hline & 14.I n \\
\hline & 15.While working in a team, we conduct discussion in order to synergize the goals. \\
\hline & 16. Any time there are problems coming up while working in a team, we try to resolve them well. \\
\hline & 1.The salary/wage I receive is decent and I feel satisfied with it. \\
\hline Satisfaction & 2.Apart from the salary/wage, I also get some other benefits/allowances \\
\hline \multirow{10}{*}{$(\mathrm{Y})$} & 3.The work I do is very interesting and fun. \\
\hline & 4.I am given all opportunities to learn and this is of course quite fun. \\
\hline & $n$ the resnonsibility and trust that I feel satisfied \\
\hline & th the existing promotion system, for it is carried out transparently and \\
\hline & 7.I am given equal opportunities as others in achieving a better position. \\
\hline & 8.The Manager always shows his concern and provides me with advices. \\
\hline & \\
\hline & 10.The Manager provides assistance when I have difficulties in my work. \\
\hline & 11.My co-workers are very intelligent and helpful at work. \\
\hline & $\begin{array}{l}\text { 12. My co-workers are very pleasant and responsible for their work; they are go } \\
\text { 13. My co-workers encourage me to do my works well so that I feel satisfied }\end{array}$ \\
\hline
\end{tabular}


Table 4. The results of the validity test of the variables of leadership style organizational culture, and job satisfaction

\begin{tabular}{|c|c|c|c|c|}
\hline Variable & & $\mathbf{r}_{\text {count }}$ & $\mathbf{r}_{\text {table }}$ & Description \\
\hline \multirow{4}{*}{$\begin{array}{l}\text { L e a d - } \\
\text { e rs hip } \\
\text { Style } \\
\text { (X1) }\end{array}$} & GK1 & 0.680 & 0.355 & Valid \\
\hline & GK2 & 0.772 & 0.355 & Valid \\
\hline & GK3 & 0.703 & 0.355 & Valid \\
\hline & GK4 & 0.678 & 0.355 & Valid \\
\hline \multirow{19}{*}{$\begin{array}{l}\text { Organi- } \\
\text { zational } \\
\text { Culture } \\
(\mathrm{X} 2)\end{array}$} & GK5 & 0.717 & 0.355 & Valid \\
\hline & GK6 & 0.723 & 0.355 & Valid \\
\hline & GK7 & 0.670 & 0.355 & Valid \\
\hline & GK8 & 0.604 & 0.355 & Valid \\
\hline & GK9 & 0.681 & 0.355 & Valid \\
\hline & GK10 & 0.655 & 0.355 & Valid \\
\hline & GK11 & 0.634 & 0.355 & Valid \\
\hline & GK12 & 0.805 & 0.355 & Valid \\
\hline & GK13 & 0.525 & 0.355 & Valid \\
\hline & $\mathrm{BO} 1$ & 0.579 & 0.355 & Valid \\
\hline & $\mathrm{BO} 2$ & 0.577 & 0.355 & Valid \\
\hline & $\mathrm{BO} 3$ & 0.788 & 0.355 & Valid \\
\hline & $\mathrm{BO} 4$ & 0.762 & 0.355 & Valid \\
\hline & $\mathrm{BO} 5$ & 0.565 & 0.355 & Valid \\
\hline & BO6 & 0.719 & 0.355 & Valid \\
\hline & BO7 & 0.522 & 0.355 & Valid \\
\hline & $\mathrm{BO} 8$ & 0.721 & 0.355 & Valid \\
\hline & BO9 & 0.610 & 0.355 & Valid \\
\hline & BO10 & 0.710 & 0.355 & Valid \\
\hline \multirow{16}{*}{$\begin{array}{l}\text { Job Sat- } \\
\text { i s f a c - } \\
\text { tion } \\
\text { (Y) }\end{array}$} & BO11 & 0.742 & 0.355 & Valid \\
\hline & BO12 & 0.626 & 0.355 & Valid \\
\hline & BO13 & 0.681 & 0.355 & Valid \\
\hline & BO14 & 0.672 & 0.355 & Valid \\
\hline & BO15 & 0.658 & 0.355 & Valid \\
\hline & BO16 & 0.719 & 0.355 & Valid \\
\hline & KK1 & 0.499 & 0.355 & Valid \\
\hline & KK2 & 0.375 & 0.355 & Valid \\
\hline & KK3 & 0.657 & 0.355 & Valid \\
\hline & KK4 & 0.627 & 0.355 & Valid \\
\hline & KK5 & 0.741 & 0.355 & Valid \\
\hline & KK6 & 0.797 & 0.355 & Valid \\
\hline & KK7 & 0.577 & 0.355 & Valid \\
\hline & KK8 & 0.764 & 0.355 & Valid \\
\hline & KK9 & 0.676 & 0.355 & Valid \\
\hline & KK10 & 0.661 & 0.355 & Valid \\
\hline
\end{tabular}

$\begin{array}{llll}\text { KK11 } & 0.814 & 0.355 & \text { Valid } \\ \text { KK12 } & 0.820 & 0.355 & \text { Valid } \\ \text { KK13 } & 0.848 & 0.355 & \text { Valid }\end{array}$

Based on the results of the validity test in Table 4, the three variables can be declared as valid because the rcount value is greater than the rtable, so the questionnaire can be used for further research.

The following are the results of the reliability test of the variables of leadership style, organizational culture, and job satisfaction which are described in Table 5.

It can be seen from the results of the reliability test in Table 5 that the three variables have a Cronbach's Alpha value of more than 0.70 and they proved that all variables are reliable.

Based on the results of the classical assumption tests, i.e normality test, linearity test, multicollinearity test and heteroscedasticity test, it is known that all variables are normally distributed, have a linear relationship, do not show any symptoms of multicollinearity, and the regression model does not have heteroscedasticity problems.

The following are the results of the normality test using the One-Sample KolmogorovSmirnov Test of the variables of leadership style, organizational culture, and job satisfaction which are described in Table 6.

Based on the results of the normality test in Table 6, it can be seen that the data in the study are normally distributed and proved by a Sig. value of greater than 0.05 .

Table 7 below showed the results of the linearity test between the variables of leadership style and job satisfaction.

Based on Table 7, it can be seen that the significant value of deviation from linearity on the leadership style variable is 0.610 which is greater than 0.05 . Therefore, it can thus be stated that there is a linear relationship between the leadership style variable and job satisfaction.

The following are the results of linearity tests between organizational culture variables and job satisfaction which are described in Table 8. 
Table 5. Reliability test results of leadership style, organizational culture and job satisfaction variables

\begin{tabular}{lrrl}
\hline \multicolumn{1}{c}{ Variable } & Cronbach's Alpha & N of item & Description \\
\hline Leadership Style (X1) & 0.903 & 13 Reliable \\
Organizational Culture (X2) & 0.913 & 16 Reliable \\
Job Satisfaction (Y) & 0.897 & 13 Reliable \\
\hline
\end{tabular}

Table 6. Normality test results

\section{One-Sample Kolmogorov-Smirnov Test}

\begin{tabular}{llr} 
& & Unstandardized Residual \\
Normal Parameters & & 33 \\
& $\mathrm{~N}$ & Mean \\
Most Extreme Differences & Std. Deviation & .0000000 \\
& Absolute & .36052711 \\
& Positive & .093 \\
Test Statistic & Negative & .088 \\
Asymp. Sig. (2-tailed) & & -.093 \\
\hline a. Test distribution is Normal. & .093 \\
b. Calculated from data. & & $.200 \mathrm{c}, \mathrm{d}$ \\
c. Lilliefors Significance Correction. & \\
d. This is a lower bound of the true significance. & \\
\hline
\end{tabular}

Based on Table 8 , it can be seen that the significant value of deviation from linearity on the organizational culture variable is 0.264 which is greater than 0.05 . Therefore, it can thus be stated that there is a linear relationship between the organizational culture variable and job satisfaction.

In Table 9, the results of the multicollinearity test are described.

The results of the multicollinearity test in Table 9 show that the value of the variance inflation factor (VIF) of the leadership style and organizational culture variables is 2.011, which is smaller than 10 , while the tolerance value of the leadership style and organizational culture variables is 0.497 , which is greater than 0.10 . The above shows that there is no symptom of multicollinearity between the variables of leadership style and organizational culture.

The following are the results of the heteroscedasticity test shown in Table 10.
Table 10 above shows that the significant value of the leadership style and organizational culture variables are 0.607 and 0.574 respectively, which is greater than 0.005 . So it can thus be stated that the regression model does not show any symptoms of heteroscedasticity.

The results of the simultaneous test ( $\mathrm{F}$ test) between the independent variables (leadership style and organizational culture) and the dependent variable (job satisfaction) are presented in Table 11 below.

The results of the F-test in Table 11 above show that the significant value is 0.000 and less than 0.005 proving that the hypothesis $\mathrm{H} 0$ is rejected and $\mathrm{H} 1$ is accepted and thus means that the variables of leadership style and organizational culture simultaneously affect the job satisfaction variable.

In Table 12 below, the results of the analysis of the coefficient determination are described.

Based on Table 12, the value of $\mathrm{R}$ Square 
Table 7. Linearity test results between leadership style variables and job satisfaction

\begin{tabular}{|c|c|c|c|c|c|c|c|}
\hline \multicolumn{8}{|c|}{ ANOVA Table } \\
\hline & & & $\begin{array}{l}\text { Sum of } \\
\text { Squares }\end{array}$ & df & $\begin{array}{l}\text { Mean } \\
\text { Square }\end{array}$ & $\mathbf{F}$ & Sig. \\
\hline \multirow{9}{*}{$\begin{array}{l}\text { Job_Satisfaction } \\
\text { Leadership_Style }\end{array}$} & $*$ B etween & (Combined) & 7.161 & 20 & .358 & 2.464 & .056 \\
\hline & Groups & & & & & & \\
\hline & & Linearity & 4.727 & 1 & 4.727 & 32.530 & .000 \\
\hline & & Deviation & 2.434 & 19 & .128 & .882 & .610 \\
\hline & & from & & & & & \\
\hline & & Linearity & & & & & \\
\hline & $\mathrm{W}$ i t h i n & & 1.744 & 12 & .145 & & \\
\hline & Groups & & & & & & \\
\hline & Total & & 8.904 & 32 & & & \\
\hline
\end{tabular}

Table 8. Linearity test results between organizational culture variables and job satisfaction

\begin{tabular}{lllrrrrr}
\hline & & ANOVA Table & & & & & \\
& & & $\begin{array}{c}\text { Sum of } \\
\text { Squares }\end{array}$ & df & $\begin{array}{c}\text { Mean } \\
\text { Square }\end{array}$ & F & Sig. \\
\hline Job_Satisfaction & $*$ B e twe e n & (Combined) & 6.600 & 18 & .367 & 2.228 & .067 \\
Organizational_Culture & Groups & Linearity & 2.678 & 1 & 2.678 & 16.270 & .001 \\
& & Deviation from & 3.922 & 17 & .231 & 1.402 & .264 \\
& \multicolumn{7}{c}{ Linearity } \\
& Within Groups & & & & & \\
& Total & 2.304 & 14 & .165 & \\
& & 8.904 & 32 & & & \\
\hline
\end{tabular}

Table 9. Multicollinearity test results

\begin{tabular}{|c|c|c|c|c|c|c|c|}
\hline \multirow[b]{3}{*}{ Model } & \multicolumn{5}{|c|}{ Coefficients $^{\mathrm{a}}$} & & \\
\hline & \multicolumn{2}{|c|}{$\begin{array}{l}\text { Unstandardized } \\
\text { Coefficients }\end{array}$} & \multirow{2}{*}{$\begin{array}{c}\text { Standardized } \\
\text { Coefficients } \\
\text { Beta }\end{array}$} & \multirow[b]{2}{*}{$\mathbf{t}$} & \multirow[b]{2}{*}{ Sig. } & \multicolumn{2}{|c|}{$\begin{array}{c}\text { Collinearity } \\
\text { Statistics }\end{array}$} \\
\hline & B & Std. Error & & & & Tolerance & VIF \\
\hline 1 (Constant) & .879 & .575 & & 1.530 & .137 & & \\
\hline Leadership_Style & .672 & .174 & .683 & 3.861 & .001 & .497 & 2.011 \\
\hline Organizational_Culture & .067 & .187 & .064 & .361 & .721 & .497 & 2.011 \\
\hline
\end{tabular}

Table 10. Heteroscedasticity test results

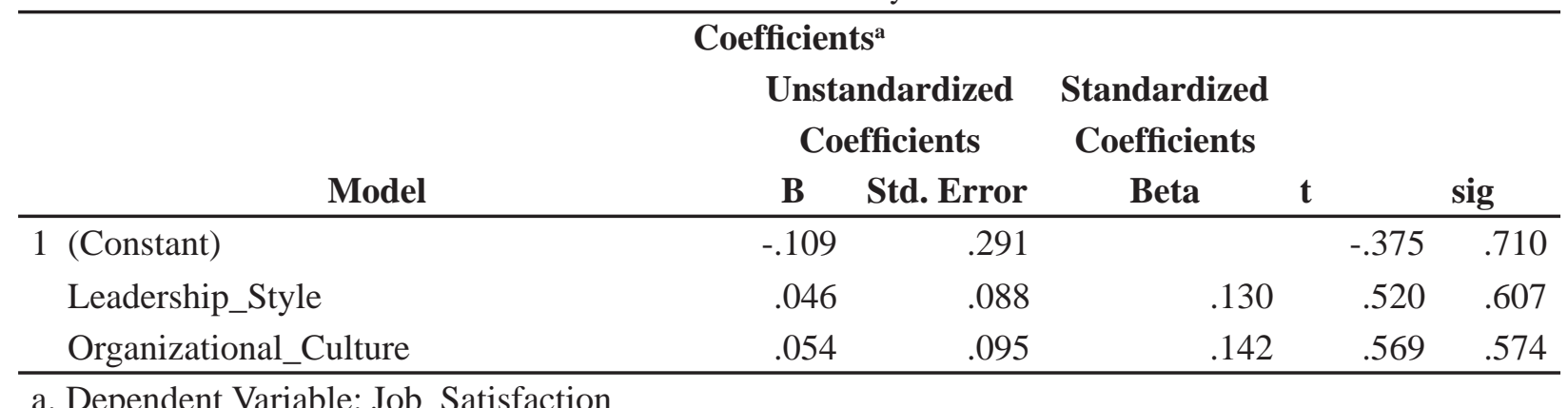


is 0.533 or 53.3 percent. This shows that the variables of leadership style and organizational culture have an influence of 53.3 percent and the remaining 46.7 percent are influenced by other unexamined variables.

The following are the results of the multiple linear regression analysis described in Table 13.

Based on the results of multiple linear regression analysis in Table 13, the following regression model can therefore be obtained:

$\mathrm{Y}=0,683 \mathrm{X} 1+0,064 \mathrm{X} 2$

The regression coefficient on the leadership style variable is 0.683 meaning that the variable has a positive influence on job satisfaction. The regression coefficient of the organizational culture variable has a value of 0.064 meaning that the variable has a positive influence on job satisfaction.

Described in Table 14 below are the results of a partial test (t-test) between the independent variables (leadership style and organizational culture) and the dependent variable (job satisfaction).

Based on the results of the t-test in Table 14 , it can be seen that the significant value of the leadership style variable is 0.001 and less than 0.005 meaning that the hypothesis $\mathrm{H} 2$ is accepted and $\mathrm{HO}$ is rejected. The variable, therefore, has a partial significant influence on the job satisfaction variable. While the organizational culture variable has no partial significant influence on the job satisfaction variable because the significant value is 0.721 which is greater than 0.005 ; therefore the hypothesis $\mathrm{H} 0$ is accepted and $\mathrm{H} 3$ is rejected.

\section{DISCUSSION}

Based on the results of the simultaneous test (F-Test), it can be stated that hypothesis $\mathrm{H} 1$ is

Table 11. Simultaneous test results (F-Test) between independent variables (leadership style and organizational culture) to dependent variables (job satisfaction)

\begin{tabular}{|c|c|c|c|c|c|c|}
\hline \multicolumn{7}{|c|}{ ANOVA $^{a}$} \\
\hline & Model & $\begin{array}{c}\text { Sum of } \\
\text { Squares }\end{array}$ & Df & $\begin{array}{c}\text { Mean } \\
\text { Square }\end{array}$ & $\mathbf{F}$ & Sig. \\
\hline \multirow[t]{3}{*}{1} & Regression & 4.745 & 2 & 2.372 & 17.112 & $.000^{\mathrm{b}}$ \\
\hline & Residual & 4.159 & 30 & .139 & & \\
\hline & Total & 8.904 & 32 & & & \\
\hline \multicolumn{7}{|c|}{ a. Dependent Variable: Job_Satisfaction } \\
\hline \multicolumn{7}{|c|}{ b. Predictors: (Constant), Organizational_Culture, Leadership_Style } \\
\hline
\end{tabular}

Table 12. Test Results of the coefficient of determination

\begin{tabular}{|c|c|c|c|c|}
\hline \multicolumn{5}{|c|}{ Model Summary } \\
\hline Model & $\mathbf{R}$ & R Square & Adjusted R Square & Std. Error of the Estimate \\
\hline 1 & $.730^{\mathrm{a}}$ & .533 & .502 & .37235 \\
\hline
\end{tabular}

Table 13. Multiple linear regression analysis test results

\begin{tabular}{|c|c|c|c|c|c|c|}
\hline \multicolumn{7}{|c|}{ Coefficient $^{\mathrm{a}}$} \\
\hline & \multirow[b]{2}{*}{ Model } & \multicolumn{2}{|c|}{$\begin{array}{l}\text { Unstandardized } \\
\text { Coefficients }\end{array}$} & \multirow{2}{*}{$\begin{array}{c}\text { Standardized } \\
\text { Coefficients } \\
\text { Beta }\end{array}$} & \multirow[b]{2}{*}{$\mathbf{T}$} & \multirow[b]{2}{*}{ Sig. } \\
\hline & & B & Std. Error & & & \\
\hline \multirow[t]{3}{*}{1} & (Constant) & .879 & .575 & & 1.530 & .137 \\
\hline & Leadership_Style & .672 & .174 & .683 & 3.861 & .001 \\
\hline & $\begin{array}{l}\text { Organizational_Cul- } \\
\text { ture }\end{array}$ & .067 & .187 & .064 & .361 & .721 \\
\hline
\end{tabular}


accepted, which means that leadership style and organizational culture simultaneously have a significant influence on job satisfaction of $\mathrm{CU}$ GKFPPK Pontianak activists. This is also in accordance with research conducted by Saputra \& Adnyani (2017), Devita (2018), and Huda (2019).

Based on the results of data processing using multiple linear regression analysis, it can be seen that the coefficient of leadership style is 0.683 , which means it has a positive influence on job satisfaction. This means that if the leadership style improves, it will increase the job satisfaction of CU GKFPPK Pontianak activists and vice versa, if the leadership style worsens, the job satisfaction of CU GKFPPK activists and vice versa, if the leadership style deteriorates, the job satisfaction of $\mathrm{CU}$ GKFPPK Pontianak activists will also decrease. Meanwhile, based on the results of the partial test (t-test) between organizational culture and job satisfaction, it was found that hypothesis $\mathrm{H} 3$ was rejected and $\mathrm{HO}$ was accepted, which means that organizational culture has no significant effect on job satisfaction of CU GKFPPK activists in Pontianak. This is in contrast to the results of research conducted by Sekarini (2017), Primasheila, Hanafi \& Bakri (2017) and Tejayadi, Laba \& Pradana (2019). So it can be stated that the culture that exists in the organization has a positive but not significant effect on the job satisfaction of CU GKFPPK Pontianak activists.

Table 14. Partial test results (t-test) between independent variables (leadership style and organizational culture) against dependent variable (job satisfaction)

\begin{tabular}{|c|c|c|c|c|c|c|}
\hline \multicolumn{7}{|c|}{ Coefficient $^{\mathrm{a}}$} \\
\hline & \multirow[b]{2}{*}{ Model } & \multicolumn{2}{|c|}{$\begin{array}{l}\text { Unstandardized } \\
\text { Coefficients }\end{array}$} & \multirow{2}{*}{$\begin{array}{c}\text { Standardized } \\
\text { Coefficients } \\
\text { Beta } \\
\end{array}$} & \multirow[b]{2}{*}{$\mathbf{t}$} & \multirow[b]{2}{*}{ Sig. } \\
\hline & & B & Std. Error & & & \\
\hline \multirow[t]{3}{*}{1} & (Constant) & .879 & .575 & & 1.530 & .137 \\
\hline & $\begin{array}{l}\text { Leadership_Style Or- } \\
\text { ganizational_Culture }\end{array}$ & .672 & .174 & .683 & 3.861 & .001 \\
\hline & Total & .067 & .187 & .064 & .361 & .721 \\
\hline
\end{tabular}

a. Dependent Variable: Job_Satisfaction

Pontianak activists will also decrease. From the results of the partial test (t-test) between leadership style and job satisfaction, it was found that hypothesis H2 was accepted, namely leadership style had a significant effect on job satisfaction of CU GKFPPK activists in Pontianak. This is in line with research conducted by Sinurat (2017) and Rashid, Roswaty \& Kurniawan (2017). So it can be stated that the manager's leadership style at CU GKFPPK Pontianak has a significant positive effect on the job satisfaction of its activists.

Based on the results of data processing using multiple linear regression analysis, it can be seen that the coefficient of organizational culture is 0.064 , which means it has a positive influence on job satisfaction. This means that if the organizational culture improves, it will increase the job satisfaction of CU GKFPPK Pontianak

\section{CONCLUSION}

Based on the results of research and discussion, it can be concluded that the leadership style and organizational culture have a simultaneous significant influence on the job satisfaction of CU GKFPPK Pontianak activists. The leadership style has a partial positive significicant influence on the job satisfaction, while the organizational culture has a partial positive but not significant effect on the job satisfaction of CU GKFPPK Pontianak activists.

\section{ACKNOWLEDGEMENT}

Thank you to the activists of CU GKFPPK Pontianak and the entire academic community of Universitas Widya Dharma Pontianak. It is suggested for further research to add variables other than leadership style, organizational culture, and job satisfaction, such as organizational 
commitment, work motivation, quality of work life, work environment, employee performance or others.

\section{REFERENCES}

Afandi, P. (2021). Manajemen Sumber Daya Manusia; Teori, Konsep dan Indikator. Pekanbaru: Zanafa Publishing.

Asghar, S., \& Oino, I. (2018). Leadership Styles and Job Satisfaction. Market Forces. 13 (1). 1-13.

Berliana, M., Siregar, N., \& Gustian, H. D. (2018). The Model of Job Satisfaction and Employee Performance. International Review of Management and Marketing. Vol. 8, Iss. 6. 41-46. 1 https://doi.org/0.32479/irmm.7183.

Devita, R. (2018). Pengaruh Gaya Kepemimpinan dan Budaya Organisasi Terhadap Kepuasan Kerja Pada PT Agung Automall Cabang Sipin di Provinsi Jambi. Jurnal Ilmiah Universitas Batanghari Jambi. Vol. 18, No. 1.

Huda, N. (2019). Pengaruh Gaya Kepemimpinan dan Budaya Organisasi Terhadap Kepuasan Kerja Karyawan YPP Darul Huda Wonodadi Blitar. REVITALISASI: Jurnal Ilmu Manajemen. 5(2). 23-30.

Isac, N., et al,.. (2021). Does Organizational Culture Influence Job Satisfaction? A Comparative Analysis of Two Multinational Companies. Review of International Comparative Management. Volume 22, Issue 2. 138-158. https://doi.org/10.24818/ RMCI.2021.2.138.

Kebede, A. M., \& Demeke, G. W. (2017). The Influence of Leadership Styles on Employees' Job Satisfaction in Ethiopian Public Universities. Contemporary Management Research. Vol. 13, No. 3. 165-176. https://doi. org/10.7903/cmr. 17668.

Khajeh, E. H. A. (2018). Impact of Leadership Styles on Organizational Performance. Journal of Human Resources Management Research. Vol. 2018 (2018), Article ID 687849. https:// doi.org/10.571/2018.687849.

Onday, O. (2016). Organizational Culture Theory: From Organizational Culture of Schein to Appreciative Inquiry of Cooperrider
\& Whitney. Elixir International Journal. 92 (2016). 39002-39008.

Primasheila, D., Hanafi, A., \& Bakri, S. A. (2017). Pengaruh Budaya Organisasi Terhadap Kepuasan Kerja Karyawan PT. Telkom Kantor Wilayah Palembang. JEMBATAN: Jurnal Ilmiah Manajemen Bisnis dan Terapan. Tahun XIV No.1.

Rashid, F. A., Roswaty, \& Kurniawan, M. (2017). Pengaruh Gaya Kepemimpinan Terhadap Kepuasan Kerja Karyawan Pada PT. Ciomas Adisatwa Palembang. Jurnal Ilmiah Ekonomi Global Masa Kini. Volume 8, No. 02. 90-94.

Saputra, I G. A. E., \& Adnyani, I G. A. D. (2017). Pengaruh Gaya Kepemimpinan dan Budaya Organisasi Terhadap Kepuasan Kerja Karyawan. E-Jurnal Manajemen Unud. Vol. 6, No. 12. 6592-6619.

Sekarini, T. (2017). Pengaruh Budaya Organisasi Terhadap Kepuasan Kerja Pegawai di Kantor Kementrian Agama Kabupaten Ciamis. Dinamika: Jurnal Ilmiah Ilmu Administrasi Negara. Vol. 4, No. 2. 331-339.

Sinurat, E. (2017). Pengaruh Gaya Kepemimpinan Terhadap Kepuasan Kerja Karyawan pada PT. Himawan Putra Medan. Jurnal Ilmiah METHONOMI. Vol. 3, No. 2.

Sutrisno, E. (2018). Budaya Organisasi. Jakarta: Prenada Media.

Tejayadi, I P. W., Laba, I N., \& Pradana, G. Y. K. (2019). The Effect of Organizational Culture on Employee Satisfaction in Mercure Resort Sanur. International Journal of Green Tourism Research and Applications. 1. 63-72. https:// doi.org/10.31940/ijogtra.v1i1.1631.

Thiagaraj, D., \& Thangaswarny, A. 2017. Theoretical Concept of Job Satisfaction a Study. International Journal of Research - Granthaalayah. Vol. 5, Iss. 6. 464-470. https://doi.org/10.29121/granthaalayah. v5.i6.2017.2057.

Utaminingsih, A. (2014). Perilaku Organisasi. Malang: UB Press.

Vasilescu, M. (2019). Leadership Styles and Theories in an Effective Management Activity. Academica Brancusi Publisher. Issue 4. 